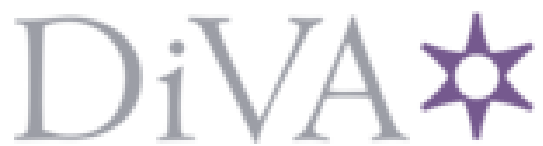

http://www.diva-portal.org

This is the published version of a paper published in Phytotaxa.

Citation for the original published paper (version of record):

Zamora, J., Diederich, P., Millanes, A., Wedin, M. (2017)

Anold familiar face: Tremella anaptychiae sp. nov. (Tremellales,Basidiomycota)..

Phytotaxa, 307: 254-262

https://doi.org/10.11646/phytotaxa.307.4.3

Access to the published version may require subscription.

N.B. When citing this work, cite the original published paper.

Permanent link to this version:

http://urn.kb.se/resolve?urn=urn:nbn:se:nrm:diva-2555 


\title{
Article
}

https://doi.org/10.11646/phytotaxa.307.4.3

\section{An old familiar face: Tremella anaptychiae sp. nov. (Tremellales, Basidiomycota)}

\author{
JUAN CARLOS ZAMORA ${ }^{1}$, PAUL DIEDERICH ${ }^{2}$, ANA M. MILLANES ${ }^{3} \&$ MATS WEDIN $^{4}$ \\ ${ }^{\prime}$ Departamento de Biología Vegetal II, Facultad de Farmacia, Universidad Complutense de Madrid, E-28040, Madrid, Spain \\ (jcsenoret@gmail.com) \\ ${ }^{2}$ Musée national d'histoire naturelle, 25 rue Munster, L-2160 Luxembourg, Luxembourg (paul.diederich@education.lu) \\ ${ }^{3}$ Departamento de Biología y Geología, Física y Química Inorgánica, Universidad Rey Juan Carlos, E-28933 Móstoles, Spain \\ ${ }^{4}$ Department of Botany, Swedish Museum of Natural History, P.O. Box 50007, SE-10405 Stockholm, Sweden
}

\begin{abstract}
Tremella anaptychiae, a lichenicolous fungus growing on Anaptychia ciliaris, is described as new. Both morphological and molecular data (DNA sequences from the ITS and 28S regions) are used to characterize and distinguish it from other Tremella s. 1. species. Tremella anaptychiae is closely related to T. parmeliarum but comparatively distantly related to other previously recognized lichenicolous species groups.
\end{abstract}

Key words: Anaptychia, lichenicolous fungi, morphology, phylogenetic analyses, Tremella, Tremellomycetes

\section{Introduction}

The genus Tremella Persoon (1794) : Fries (1821) has traditionally been considered a huge and non-monophyletic assembly of mycoparasitic fungi. Tremella s. 1. is characterised by certain morphological synapomorphies; dolipore septa with cupulate-vesiculose parenthesomes, basidia that are often septate and in which each hypobasidial cell grows to form a single and distinct epibasidium, and usually the presence of specialized cells, called haustoria, involved in the parasitic activity (Bandoni 1984, Diederich 1996, Chen 1998, Millanes et al. 2011). More than 50 species are known to exclusively parasitize specific lichenized fungal hosts, and the number is continuously increasing (Diederich 1986, 1996, 2003, 2007, Diederich \& Marson 1988, Diederich \& Christiansen 1994, Sérusiaux et al. 2003, Zamora et al. 2011, 2016, Millanes et al. 2012, 2014a, 2015, Diederich et al. 2014, Ariyawansa et al. 2015, Lindgren et al. 2015). This big heterogeneous group has recently been divided into several monophyletic genera (Liu et al. 2016), but most lichenicolous species still remain as "Tremella s. 1." awaiting a better resolved phylogeny and further research to find morphological or physiological synapomorphic characters.

One of these lichenicolous species is known to grow associated with the lichen-forming fungus Anaptychia ciliaris (Linnaeus 1753: 1144) Körb. ex Massalongo (1853: 35). It was first noted and shortly described and illustrated by Diederich (1996), who left it unnamed as "Tremella sp. 5" due to the scarcity of the material (a single basidioma) available at that time. During subsequent years, more specimens have been collected, and the aim of the present paper is to formally describe this taxon.

\section{Material and methods}

\section{Morphology}

The morphological study was based on nine specimens collected either by the authors or collaborators. General methodology and terminology follows Diederich (1996) and Zamora et al. (2016). Micromorphological study was done using hand-cut sections mounted and stained with Congo red in 10\% ammonia, phloxin $\mathrm{B}$ in $5 \% \mathrm{KOH}$ or a mixture of Congo red and phloxin B in 5\% KOH. Spore amyloidity was tested with Melzer's reagent. Measurements were made in $\mathrm{KOH}$ solution. Basidiospore length:width ratio was expressed as Q, and basidiospore shape terminology follows Bas (1969). Microscopic photographs were taken using a Leitz Orthoplan microscope coupled to a Canon EOS $50 \mathrm{D}$ digital camera. 


\section{DNA extraction, PCR amplification, sequencing, and phylogenetic analyses}

Taxon sampling consisted of three specimens of the new species, in addition to specimens of Tremella s. 1. species parasitizing Caliciales (T. christiansenii Diederich (1996: 60), T. dirinariae Diederich, Millanes \& Wedin in Ariyawansa et al. (2015: 239), T. phaeophysciae Diederich \& M.S. Christ. in Diederich (1996: 143)) plus other representative specimens of the Tremellales (TABLE I). These included: (i) the type species of the genus Tremella (Tremella mesenterica (Schaeffer 1774: 108) Retzius (1769: 249)); (ii) Tremella fuciformis Berkeley (1856: 277) as representative of the Fuciformis group distinguished by Chen (1998); (iii) representatives of the Aurantia and Indecorata groups distinguished also by Chen (1998), which have recently been assigned the generic names Naematelia Fries (1818: 370) and Pseudotremella X.Z. Liu, F.Y. Bai, A.M. Yurkov, M. Groenew. \& Boekhout in Liu et al. (2016: 129), respectively (Liu et al. 2016); (iv) representatives of three groups of lichenicolous species distinguished by Millanes et al. (2011), and (v) lichenicolous taxa with a micro or macromorphology similar to that of the new species. Cryptotrichosporon anacardii Okoli \& Boekhout in Okoli et al. (2007: 348) and Trichosporon ovoides Behrend (1890: 467) were used as outgroup based on Liu et al. (2016). Species names, voucher information, and GenBank accession numbers are provided (TABLE I).

TABLE 1. Sequences newly produced (bold), or downloaded from GenBank, with culture reference, or specimen data. Two strain numbers for Saytozyma podzolica correspond to replicates of the same culture deposited in different collections with distinct identification codes. Two strain numbers for Sterigmatosporidium polymorphum correspond to two conspecific strains according to Kirschner et al. (2001).

\begin{tabular}{|c|c|c|c|c|}
\hline Species name & Culture & Specimen data & ITS & nLSU \\
\hline Carcinomyces effibulatus & & Sweden, Santos s.n. (S-F40014) & AF444315 & AF189842 \\
\hline Cryptococcus neoformans & B-3501A & & BR000310 & BR000310 \\
\hline Naematelia aurantia & CBS 6965 & & AF444315 & AF189842 \\
\hline Pseudotremella moriformis & RJB 2846-8 & & AF042426 & AF042244 \\
\hline Saytozyma flava & CBS 331 & & AF444338 & AF075497 \\
\hline Saytozyma podzolica & JCM 10452/CBS 6819 & & AB035576 & AF075481 \\
\hline Sterigmatosporidium polymorphum & CBS 8088/IGC 5647 & & AF444320 & AY032662 \\
\hline Tremella anaptychiae-a (Type) & & $\begin{array}{l}\text { Spain, Zamora \& Zamora s.n. } \\
\text { (AM499; holotype MAF-Lich. } \\
\text { 21306) }\end{array}$ & KY950297 & KY950300 \\
\hline Tremella anaptychiae-b & & $\begin{array}{l}\text { Spain, 2005, Pérez-Ortega s.n. } \\
\text { (AM130; MAF-Lich) }\end{array}$ & KY950298 & KY950301 \\
\hline Tremella anaptychiae-c & & $\begin{array}{l}\text { Sweden, 2012, Knutsson s.n. } \\
\text { (AM493; S) }\end{array}$ & KY950299 & KY950302 \\
\hline Tremella caloplacae & & France, Sérusiaux s.n. (S-F102489) & JN053469 & JN043574 \\
\hline Tremella cetrariicola & & Finland, Suija s.n. (S-F102413) & JN053490 & JN043596 \\
\hline Tremella christiansenii & & $\begin{array}{l}\text { Denmark, Christiansen } 607 \text { (herb. } \\
\text { Diederich) }\end{array}$ & - & JN043577 \\
\hline Tremella cladoniae & & Estonia, Suija 872 (TU-45019) & JN053477 & JN043583 \\
\hline Tremella coppinsii & & Estonia, Suija 38a (TU-38637) & JN053496 & JN043602 \\
\hline Tremella dirinariae & & U.S.A., Harris 37673 (NY) & KR058780 & KR058785 \\
\hline Tremella hypogymniae & & Sweden, Wedin 6892 (UPS) & JN053484 & JN043590 \\
\hline Tremella fuciformis & CBS 6970 & & JN053466 & JN043571 \\
\hline Tremella lobariacearum & & $\begin{array}{l}\text { Madeira, Diederich } 4935 \text { (S- } \\
\text { F102418) }\end{array}$ & JN053473 & JN043579 \\
\hline Tremella mesenterica & & Sweden, Ryman 9146 (S-F102411) & JN053463 & JN043568 \\
\hline Tremella parmeliarum & & $\begin{array}{l}\text { Canary Islands, Diederich } 16574 \text { (S- } \\
\text { F102497) }\end{array}$ & JN053511 & JN043618 \\
\hline Tremella pertusariae & & France, Diederich 16331 (S-F102502) & JN053494 & JN043600 \\
\hline Tremella phaeophysciae & & $\begin{array}{l}\text { Luxembourg, Diederich } 12429 \text { (S- } \\
\text { F102505) }\end{array}$ & JN053479 & JN043585 \\
\hline $\begin{array}{l}\text { Trimorphomyces papilionaceus } \\
\text { Outgroup }\end{array}$ & CBS 443.92 & & AF444483 & AF075491 \\
\hline Cryptotrichosporon anacardii & CBS 6241 & & AF190007 & AF075498 \\
\hline Trichosporon ovoides & CBS 7556 & & AF444439 & AF075523 \\
\hline
\end{tabular}




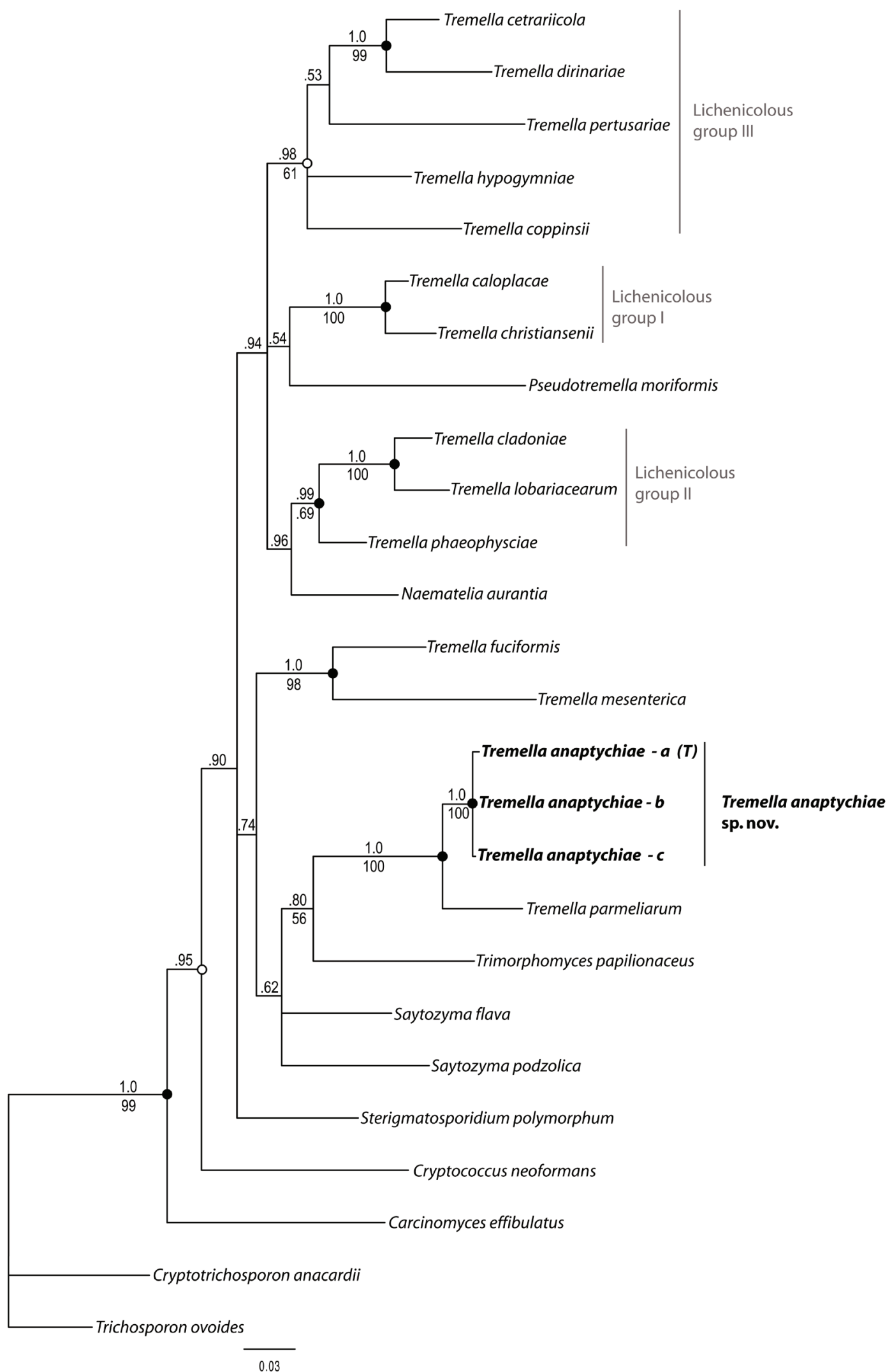

FIGURE 1. Fifty-percent majority rule Bayesian consensus phylogram with average branch lengths, from the combined analyses of ITS1, 5.8S, ITS2, and 28S datasets. Bayesian Posterior Probability values are indicated over the branches, and bootstrap values obtained in the maximum likelihood analysis are added below the branches. White circles represent nodes supported only in the Bayesian analysis. Black circles represent nodes supported in both Bayesian and ML analyses. BPP values $\geq 0.5$ are indicated above the branches, and ML bootstrap values $\geq 50 \%$, below branches. The newly described species is highlighted in bold font, and the type specimen is indicated with (T). Some lichenicolous groups distinguished by Millanes et al. (2011) are indicated in grey in the right margin. Branch lengths are scaled to the expected number of nucleotide substitutions per site. 
DNA extractions and PCR amplifications were achieved following Millanes et al. (2012). We amplified the nuc rDNA internal transcribed spacer 1 (ITS1), 5.8S, internal transcribed spacer 2 (ITS2) and a fragment of approximately $500 \mathrm{bp}$ in the rDNA 28S region with the primer pair ITS1F (Gardes \& Bruns 1993)/BasidLSU3-3 (Millanes et al. 2011). An additional and overlapping fragment of the rDNA $28 \mathrm{~S}$ region, of approximately $1000 \mathrm{bp}$, was amplified with the primer pair BasidLSU1-5 (Millanes et al. 2011)/LR5 (Vilgalys \& Hester 1990). Sequence alignments (TreeBase accession 20905) were performed following Millanes et al. (2012). Dataset congruence was assessed manually by analyzing the datasets separately by maximum likelihood bootstrapping. Conflict among clades was considered significant if a significantly supported clade (bootstrap support $\geq 70 \%$; Hillis \& Bull 1993) for one marker was contradicted with significant support by another. Datasets were combined if no incongruences were found.

Bayesian analyses were conducted following Millanes et al. (2012) with minor modifications. We considered ITS1, 5.8S and ITS2 independent partitions, as was suggested by Gaya et al. (2011) and Petkovits et al. (2011). Likelihood models were selected for each of the three gene regions with the Akaike information criterion (AIC) as implemented in jModeltest (Posada 2008). A GTR $+\Gamma$ model was selected for the ITS1, a SYM + I model was selected for the 5.8S, a SYM $+\Gamma$ model was selected for ITS2 and a GTR $+\mathrm{I}+\Gamma$ model was selected for $28 \mathrm{~S}$. Three parallel runs were executed, each with five chains four of which were incrementally heated with a temperature of 0.15 . The analysis was diagnosed for convergence every 100000 generations, measured as the average standard deviation of splits across runs in the last half of the analysis. Every 100th tree was saved. The first half of the run was discarded as burn-in.

Maximum likelihood (ML) analyses were conducted in RAxMLGUI 1.3 (Silvestro \& Michalak 2012), a graphical front-end for RAxML (Stamatakis 2006), with the GTRGAMMA model of nucleotide substitution applied to all partitions. We performed a thorough ML search with 100 runs and assessed node support thorough bootstrap using 1000 bootstrap pseudo-replicates. Significant support is considered as BPP values $\geq 0.95$ in the Bayesian analysis, and bootstrap values $\geq 70 \%$ in the ML analysis.

\section{Results}

\section{Phylogenetic results}

We generated six new sequences, which were aligned together with sequences already available in GenBank (Table 1). Two data matrices were produced, one including ITS and one including $28 \mathrm{~S}$ rDNA. The combined matrix contained 1262 characters (ITS1: 1-78; 5.8S: 79-231; ITS2: 232-335; 28S rDNA: 336-1262). The ln-likelihood value of the best tree obtained from the ML analysis was -7993.068784. The Bayesian analysis halted after 1600000 generations. The average standard deviation of split frequencies across runs was $0.009(<0.01)$, which indicated convergence of the three runs. A majority-rule consensus tree was constructed from the 24000 trees of the stationary tree sample.

The consensus 50\% majority-rule phylogram of the Bayesian analysis and the ML phylogram yielded the same topology concerning significantly supported clades. Therefore, only the Bayesian phylogram is shown, with BPP and ML bootstrap values indicated at branches (Fig. 1). The three specimens of the new species (Tremella anaptychiae) formed a strongly supported clade (1.0 BPP, $100 \% \mathrm{BS})$, being sister to one specimen of T. parmeliarum Diederich (1996: 125). This last relationship also received full support (1.0 BPP, 100\% BS). The lichenicolous species groups defined by Millanes et al. (2012) were also recovered here, the lichenicolous group I with full support (1.0 BPP, 100\% BS), while the lichenicolous groups II and III received significant support only from the Bayesian analysis (0.96 and $0.98 \mathrm{BPP}$, respectively). The clade formed by T. anaptychiae and T. parmeliarum is not closely related to any of those lichenicolous groups (Fig. 1).

\section{Taxonomy}

Tremella anaptychiae J.C. Zamora \& Diederich, sp. nov. (Fig. 2)

MycoBank MB 821018.

Diagnosis:-Basidiomata growing parasitically on different parts of the thallus of Anaptychia ciliaris, cream-coloured to blackish, 0.2-2 $\mathrm{mm}$ in diameter; context hyphae clampless, thick-walled; basidia two-celled and stalked, stalk 2-21(24) $\mu \mathrm{m}$ long, basidial upper part 15-20 × 10-15 $\mu \mathrm{m}$, septum oblique or longitudinal, more rarely transverse; basidiospores 5.5-9 × 5-9 $\mu \mathrm{m}$; further distinguished by its characteristic ITS-28S rDNA sequences.

Etymology:-Growing on Anaptychia. 


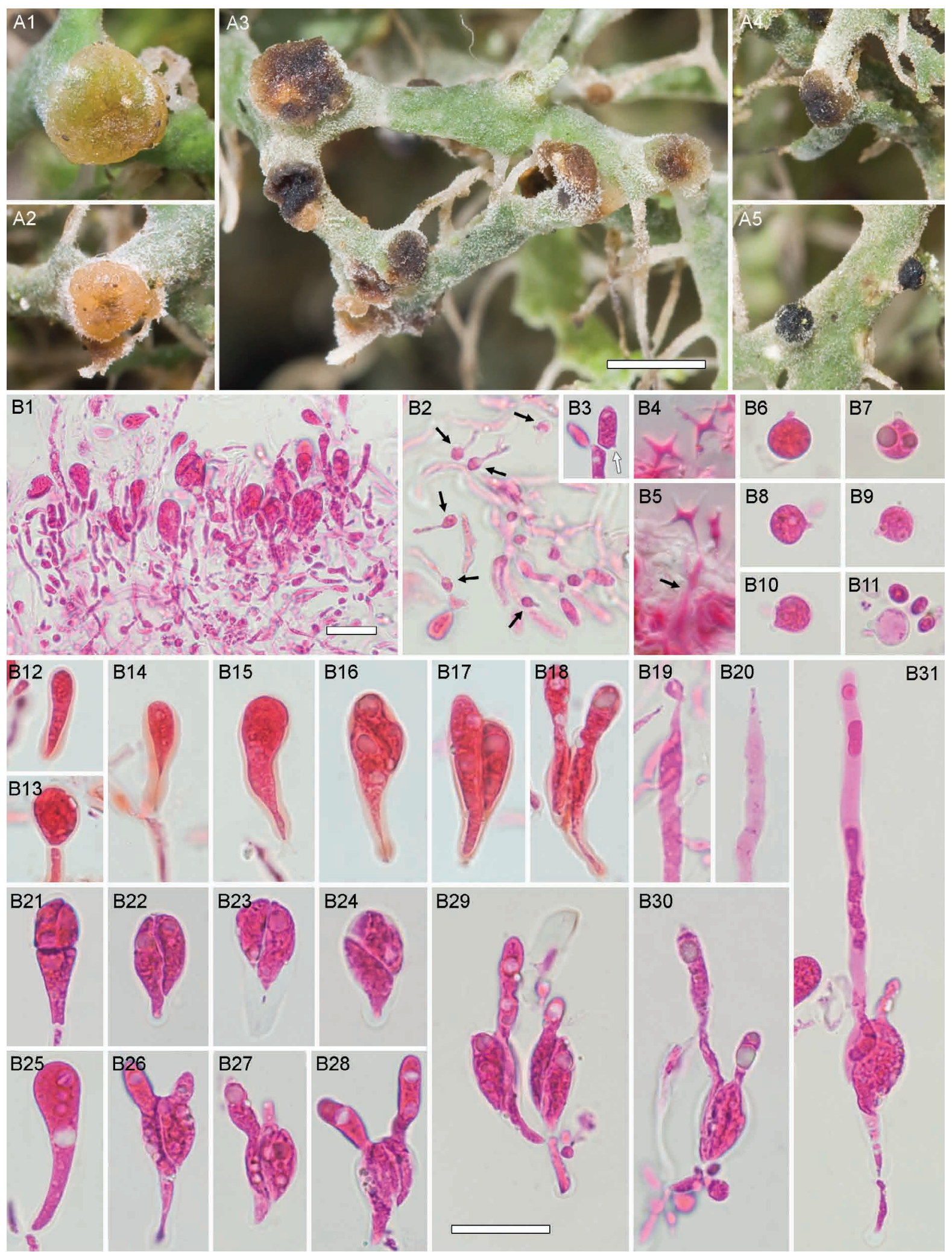

FIGURE 2. Morphological characteristics of T. anaptychiae, A morphological variation of the basidiomata on the host thallus, B micromorphological features; B1 hymenium; B2 young hyphae with haustorial branches (black arrows); B3 young cell (perhaps a probasidial initial) with a spur-like basal swelling (white arrow); B4-B5 asteroconidia and conidiogenous cell (black arrow); B6-B11 basidiospores, in B11 collapsed basidiospore with yeast-like cells; B12-B18 basidial development, note that basidia are often thick-walled, particularly towards the stalk; B19-B20 epibasidia with an apical sterigma, in B19 with an asymmetrically attached young basidiospore; B21-B24 basidia with transverse (B21), almost longitudinal (B22) or oblique (B23, B24) septa; B25 young long-stalked basidium. B26B31; mature basidia with epibasidia in different degrees of development; B1-B11 and B19-B31, phloxin B in 5\% KOH; B12-B18, Congo red and phloxin B in 5\% KOH. Scale bars: A=1 mm (all photographs at the same scale), B=20 $\mu \mathrm{m}(\mathrm{B} 2-\mathrm{B} 31$ at the same scale). B4-B5 from E. Zimmermann 1065, all other photographs from the holotype. 


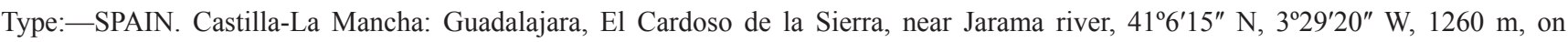
Anaptychia ciliaris thallus, on Crataegus monogyna branches, 16.4.2011, J.C. Zamora \& B. Zamora s.n., holotype MAF-Lich. 21306 (DNA: AM499), isotypes in AH, MA-Fungi, S, and herb. Diederich.

Description:-Basidiomata subglobose to somewhat tuberculate when old, waxy-gelatinous, cream-coloured, pinkish, brownish or blackish, rarely with greenish shades, $0.2-2 \mathrm{~mm}$ diam, growing on the thallus (both surfaces), including cilia of the host, more rarely on the margin of apothecia (Fig. 2A). Context hyphae and subbasidial hyphae thickwalled, slender, (2.5)3-5.5(6.5) $\mu \mathrm{m}$ diam., clampless, but small spur-like swellings (perhaps pseudoclamps) have been seen at few septa, exceptionally with clamps. Haustorial branches very abundant, mother cell subglobose to broadly ellipsoid, 3-4 × 3-3.5 $\mu \mathrm{m}$ diam., haustorial filament 1.5-7(11) $\times 1 \mu \mathrm{m}$, unbranched or with few and short apical branches (Fig. 2B2). Hymenium well-developed, hyaline or with a subtle brownish tinge, containing numerous probasidia (Fig. 2B1). Hyphidia absent or indistinct. Probasidial initials mostly claviform to narrowly ellipsoid, rarely subglobose, with a long, thick-walled stalk, clampless, but often with an asymmetric attachment to the subtending hypha, rarely with a small spur-like swelling (perhaps a pseudoclamp, Fig. 2B3, 2B12-B15). Mature basidia twocelled, with often longitudinal or oblique septa, sometimes transverse, stalked, thick-walled (walls thicker towards the base); stalk 2-21(24) $\mu \mathrm{m}$ long; upper part (without stalk) ellipsoid, claviform or subglobose, $15-20 \times 10-15 \mu \mathrm{m}$; epibasidia subcylindrical or slightly dilated close to the apex, 3-4(5) $\times 10-30(60) \mu \mathrm{m}$, developing an apical sterigma, 3-5 $\mu \mathrm{m}$ long (Fig. 2B16-B31). Basidiospores globose to subglobose, sometimes broadly ellipsoid, 5.5-9 $\times 5-9 \mu \mathrm{m}$, inamyloid, germinating by repetition to form ballistoconidia (similar to basidiospores but slightly smaller) and blastic conidia (yeast-like cells), the latter ellipsoid, 4-6 × 3-5 $\mu \mathrm{m}$ (Fig. 2B6-B11). Asteroconidia sometimes present, with 4 arms, $10-15 \mu \mathrm{m}$ in diam., individual arms 3.5-8 $\mu \mathrm{m}$ long, basal arm often longer and connected to the conidiogenous cell; conidiogenous cells 17-26 $\mu \mathrm{m}$ long, 1.5-4 $\mu \mathrm{m}$ in diam., with a few or several branches close to the apex up to 4 $\mu \mathrm{m}$ long, very numerous in the hymenium of some basidiomata in which basidia are sparse (Fig. 2B4-B5).

Additional specimens examined (on Anaptychia ciliaris, unless otherwise indicated):-ITALY. Calabria: Cosenza, Pollino timpa di Porac, 1300 m, [no date], [no collector] (CLU). MACEDONIA. Sar planina: Rudoka, Popova sapka W Tetovo, Hänge W der Bergstation der Bergbahn, 8.9.1977, J. Hafellner 3906 (herb. Hafellner at GZU). SPAIN. Canary Islands: Gran Canaria, Strasse GC150 Tejado-Pico de las Nieves, nähe Forsthaus, $27.988839^{\circ} \mathrm{N}, 5.593184^{\circ} \mathrm{W}, 1600 \mathrm{~m}$, 2014, E. Zimmermann 1065 (herb. Diederich). La Palma, Cumbre vieja, Puntade los Roqus, BE exp. Felswand, 2000 m, [no date], F. Berger 10454 (herb. Berger). SPAIN, Iberian Peninsula. Castilla-La Mancha: Guadalajara, Condemios de Arriba, Aldeanueva de Atienza, 31.10.2009, J.C. Zamora s.n. (MAF-Lich. 21307). La Rioja, Villoslada de Cameros, hayedo cerca de Puente Ra, $1260 \mathrm{~m}, 42^{\circ} 03^{\prime} \mathrm{N}, 02^{\circ} 42^{\prime} \mathrm{W}, 30.3 .2005$, S. Pérez-Ortega s.n. (MAF-Lich. ) (DNA: AM130). Navarra, Lezaun, entrada al puerto de Lizárraga, [no date], J. Etayo s.n. (MA-Lichen 4014). País Vasco, Ullibarri, [no

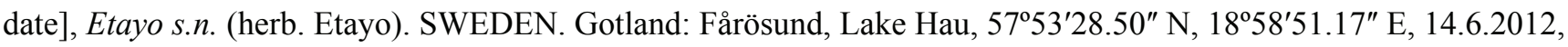
T. Knutsson s.n. (S ) (DNA: AM493).

Ecology and distribution:- The new species is known from Italy, Macedonia, Spain (incl. Canary Islands), and Sweden. It seems to be confined to Anaptychia ciliaris. As for most lichenicolous fungi, the distribution is primarily dependent on the host. Anaptychia ciliaris is a palearctic species, known from Scandinavia, the British Isles, Central and Southern Europe, north Africa, the Canary Islands and eastern Europe including Turkey, with scattered Asian records (Rose 1998), growing mainly within the "temperate broadleaf and mixed forests" and the "Mediterranean forest, woodlands and scrub" biomes (Olson et al. 2001). Since the studied samples of T. anaptychiae indeed cover an important part of this distribution, it is expected that it may be present in any place where the host is common.

\section{Discussion}

Tremella anaptychiae is a well-delimited species, mainly characterized by the clampless hyphae, thick-walled, stalked, two-celled basidia, relatively small basidiospores, and by growing on different parts of the thallus of Anaptychia ciliaris, but not on the hymenium of the host. One of us (PD) has studied a specimen on A. setifera (Mereschk.)

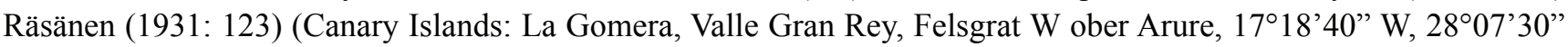
N, 800 m, an W-exponierten Steilflächen, 21.2.1991, J. Hafellner 33596 [herb. Hafellner at GZU]) that has much darker, almost black basidiomata, but is immature, and therefore has provisionally not been included within Tremella anaptychiae, awaiting more material on that host. 
The new species forms a strongly supported clade with T. parmeliarum (Fig. 1), a species normally also inducing the formation of very conspicuous, often dark galls or basidiomata on the thallus of Parmotrema spp. (but see Diederich (1996) concerning some specimens of T. parmeliarum on Parmotrema perforatum (Wulfen in Jacquin 1786: 116) Massalongo (1860: 248)), with basidia of about the same size and a similar septation pattern, and lacking true clamp-connections, as in T. anaptychiae. However, in addition to parasitizing a different host, T. parmeliarum is distinguished by its sessile to shortly stalked, 2-4-celled basidia (Diederich 1996). Both taxa are relatively isolated from a phylogenetic point of view, although their precise phylogenetic placement is unclear due to the low support of the backbone.

There are a number of lichenicolous species that may resemble $T$. anaptychiae in several morphological features. One of them is T. pertusariae Diederich (1996: 133), because of the clearly stalked basidia, often with thickened walls towards the base and the stalk, slender subbasidial hyphae, with less numerous septa than in most lichenicolous species, and the absence of clamp connections. However, T. pertusariae is well separated by the much larger 2-4-celled basidia, larger basidiospores, and by growing mostly in the hymenium, more rarely on the thallus, of Pertusaria spp. (Diederich 1996). Tremella harrisii Diederich (1996: 85) also has many characteristics in common: in this species basidia are about the same size and shape but are provided with basal clamp-connections and are 2-4-celled. It has been found parasitizing the genera Trypethelium and Polymeridium, being one of the few lichenicolous heterobasidiomycetes known on different host genera. The yet undescribed Tremella sp. 6 in Diederich (1996: 175) has two-celled stalked basidia that are smaller than in T. anaptychiae and have basal clamp-connections; it also differs in the host selection, as it parasitizes a Leptogium species.

Finally, since recent studies have shown that host specificity is important to characterize certain evolutionary lineages in this group of fungi (Millanes et al. 2014b; Zamora et al. 2016), T. anaptychiae has to be compared with the other Tremella species known to parasitize Caliciales hosts. None of them is morphologically similar to T. anaptychiae, since T. phaeophysciae and T. rinodinae Diederich \& M.S. Christ. in Diederich (1996: 154), growing on Phaeophyscia orbicularis (Necker 1771: 88) Moberg (1977: 44) and Rinodina gennarii Baglietto (1861: 17) respectively, have twocelled basidia with a transverse septum (very rarely longitudinal in $T$. rinodinae), while $T$. christiansenii, growing on Physcia spp., has larger basidiospores and mostly two-celled, sessile basidia, in which each cell elongates and grows independently before forming the epibasidia. According to our phylogenetic analyses, neither T. phaeophysciae nor $T$. christiansenii are closely related to T. anaptychiae (Fig. 1), while for T. rinodinae molecular data are not available yet. Tremella dirinariae, a species known only from the type specimen on Dirinaria in Florida, has smaller basidiomata, rarely exceeding $0.35 \mathrm{~mm}$ in diam., and slightly smaller basidia, $17-24 \times 6.5-10 \mu \mathrm{m}$ (stalk included), with a basal clamp; in addition, it is phylogenetically distant to T. anaptychiae, but related to the clade including T. cetrariicola Diederich \& Coppins in Diederich (1996: 57), T. coppinsii Diederich \& G. Marson (1988: 175), and T. hypogymniae Diederich \& M.S. Christ. in Diederich (1996: 90) (lichenicolous group III, Fig. 1).

\section{Acknowledgements}

We want to express our gratitude to F. Berger, J. Etayo, T. Knutsson, S. Pérez-Ortega and E. Zimmermann for making their specimens available for this study, and to J. Hernanz for his aid with the microphotography equipment. The research was done while the first author was in receipt of funding from the Ministerio de Economía y Competitividad (Juan de la Cierva-formación program, FJCI-2014-19801, Spain). The research was supported by the grant 2016-27 4.3 from The Swedish Taxonomy Initiative (Svenska artprojektet) administered by the Swedish Species Information Center (ArtDatabanken) to MW.

\section{References}

Ariyawansa, H.A., Hyde, K.D., Jayasiri, S.C., Buyck, B., Chethana, K.W.T., Dai, D.Q., Dai, Y.C., Daranagama, D.A., Jayawardena, R.S., Lücking, R., Ghobad-Nejhad, M., Niskanen, T., Thambugala, K.M., Voigt, K., Zhao, R.L., Li, G.J., Doilom, M., Boonmee, S., Yang, Z.L., Cai, Q., Cui, Y.Y., Bahkali, A.H., Chen, J., Cui, B.K., Chen, J.J., Dayarathne, M.C., Dissanayake, A.J., Ekanayaka, A.H., Hashimoto, A., Hongsanan, S., Jones, E.B.G., Larsson, E., Li, W.J., Li, Q.R., Liu, J.K., Luo, Z.L., Maharachchikumbura, S.S.N., Mapook, A., McKenzie, E.H.C., Norphanphoun, C., Konta, S., Pang, K.L., Perera, R.H., Phookamsak, R., Phukhamsakda, C., Pinruan, U., Randrianjohany, E., Singtripop, C., Tanaka, K., Tian, C.M., Tibpromma, S., Abdel-Wahab, M.A., Wanasinghe, D.N., 
Wijayawardene, N.N., Zhang, J.F., Zhang, H., Abdel-Aziz, F.A., Wedin, M., Westberg, M., Ammirati, J.F., Bulgakov, T.S., Lima, D.X., Callaghan, T.M., Callac, P., Chang, C.H., Coca, L.F., Dal-Forno, M., Dollhofer, V., Fliegerová, K., Greiner, K., Griffith, G.W., Ho, H.M., Hofstetter, V., Jeewon, R., Kang, J.C., Wen, T.C., Kirk, P.M., Kytövuori, I., Lawrey, J.D., Xing, J., Li, H., Liu, Z.Y., Liu, X.Z., Liimatainen, K., Lumbsch, H.T., Matsumura, M., Moncada, B., Nuankaew, S., Parnmen, S., Santiago, A., Sommai, S., Song, Y., Souza, C.A.F., Souza-Motta, C.M., Su, H.Y., Suetrong, S., Wang, Y., Wei, S.F., Yuan, H.S., Zhou, L.W., Réblová, M., Fournier, J., Camporesi, E., Luangsa-ard, J.J., Tasanathai, K., Khonsanit, A., Thanakitpipattana, D., Somrithipol, S., Diederich, P., Millanes, A.M., Common, R.S., Stadler, M., Yan, J.Y., Li, X.H., Eberhardt, U., Simonini, G., Wen, H.A. \& Chen, X.H. (2015) Fungal Diversity Notes 111-252 - Taxonomic and phylogenetic contributions to fungal taxa. Fungal Diversity 75 (1): $27-274$. http://dx.doi.org/10.1007/s13225-015-0346-5

Baglietto, F. (1861) Nuove specie di Licheni. Commentario della Società Crittogamologica Italiana 1: 17-24.

Bandoni, R.J. (1984) The Tremellales and Auriculariales: an alternative classification. Transactions of the Mycological Society of Japan 25: 489-530.

Bas, C. (1969) Morphology and subdivision of Amanita and a monograph of its section Lepidella. Persoonia 5: 285-579.

Behrend, G. (1890) Ueber Trichomycosis nodosa (Juhel-Renoy); Piedra (Osorio). Berliner Klinische Wochenschrift 27: $464-467$.

Berkeley, M.J. (1856) Decades of fungi. Decades LXI-LXII. Rio Negro fungi. Hooker's Journal of Botany and Kew Garden Miscellany 8: $272-280$.

Chen, C.-J. (1998) Morphological and molecular studies in the genus Tremella. Bibliotheca Mycologica 174: 1-225.

Diederich, P. (1986) Lichenicolous fungi from the Grand Duchy of Luxembourg and surrounding areas. Lejeunia n. s. 119 : 1-26.

Diederich, P. (1996) The lichenicolous heterobasidiomycetes. Bibliotheca Lichenologica 61: 1-198.

Diederich, P. (2003) New species and new records of American lichenicolous fungi. Herzogia 16: 41-90.

Diederich, P. (2007) New or interesting lichenicolous heterobasidiomycetes. Opuscula Philolichenum 4: 11-22.

Diederich, P. \& Christiansen, M.S. (1994) Biatoropsis usnearum Räsänen, and other heterobasidiomycetes on Usnea. Lichenologist 26: 47-66. https://doi.org/10.1017/S002428299400006X

Diederich, P. \& Marson, G. (1988) Tremella coppinsii, a new lichenicolous basidiomycete from Sarawak. Notes from the Royal Botanic Garden, Edinburgh 45: 175-176.

Diederich, P., Millanes, A.M. \& Wedin, M. (2014) Tremella umbilicariae (Tremellomycetes, Basidiomycota), a new lichenicolous species on Umbilicaria from Peru. Bulletin de la Société des naturalistes luxembourgeois 115: 167-172.

Fries, E.M. (1818) Observationes mycologicae 2, 372 pp.

Fries, E.M. (1821) Systema mycologicum 1, 520 pp.

Gardes, M. \& Bruns, T.D. (1993) ITS primers with enhanced specificity for basidiomycetes, application to the identification of mycorrhizae and rusts. Molecular Ecology 2: 113-118. https://doi.org/10.1111/j.1365-294X.1993.tb00005.x

Gaya, E., Redelings, B.D., Navarro-Rosinés, P., Llimona, X., de Cáceres, M. \& Lutzoni, F. (2011) Align or not to align? Resolving species complexes within the Caloplaca saxicola group as a case study. Mycologia 103: 361-378. https://doi.org/10.3852/10-120

Hillis, D.M. \& Bull, J.J. (1993) An empirical test of bootstrapping as a method for assessing confidence in phylogenetic analyses. Systematic Biology 42: 182-192. https://doi.org/10.1093/sysbio/42.2.182

Jacquin, N.J. (1786) Collectanea ad botanicam, chemiam, et historiam naturalem spectantia 1. 368 pp.

Kirschner, R., Sampaio, J.P., Gadanho, M., Weiß, M. \& Oberwinkler, F. (2001) Cuniculitrema polymorpha (Tremellales, gen. nov. and sp. nov.), a heterobasidiomycete vectored by bark beetles, which is the teleomorph of Sterigmatosporidium polymorphum. Antonie van Leeuwenhoek 80: 149-161.

https://doi.org/10.1023/A:1012275204498

Linnaeus, C. (1753) Species plantarum. Vol. 1, Ed.2. Laurentii Salvii, Holmiae, 560 pp.

Lindgren, H., Diederich, P., Goward, T. \& Myllys, L. (2015) The phylogenetic analysis of fungi associated with lichenized ascomycete genus Bryoria reveals new lineages in the Tremellales including a new species Tremella huuskonenii hyperparasitic on Phacopsis huuskonenii. Fungal Biology 119: 844-856. https://doi.org/10.1016/j.funbio.2015.06.005

Liu, X.-Z., Wang, Q.-M., Göker, M., Groenewald, M., Kachalkin, A.V., Lumbsch, H.T., Millanes, A.M., Wedin, M., Yurkov, A.M., Boekhout, T. \& Bai, F.-Y. (2016) Towards an integrated phylogenetic classification of the Tremellomycetes. Studies in Mycology 81: $85-147$.

https://doi.org/10.1016/j.simyco.2015.12.001

Massalongo, A. (1853) Memórie Lichenographiche. Verona, 185 pp. 
Massalongo, A.B. (1860) Esame comparativo di alcune genere di licheni. Atti dell'Istituto Veneto Scienze 5: 247-276.

Millanes, A.M., Diederich, P., Ekman, S. \& Wedin, M. (2011) Phylogeny and character evolution in the jelly fungi (Tremellomycetes, Basidiomycota, Fungi). Molecular Phylogenetics and Evolution 61: 12-28. https://doi.org/10.1016/j.ympev.2011.05.014

Millanes, A.M., Westberg, M., Wedin, M. \& Diederich, P. (2012) Tremella diploschistina (Tremellomycetes, Basidiomycota, Fungi), a new lichenicolous species growing on Diploschistes. Lichenologist 44: 321-332. https://doi.org/10.1017/S0024282911000788

Millanes, A.M., Diederich, P., Westberg, M., Knutsson, T. \& Wedin, M. (2014a) Tremella rhizocarpicola sp. nov. and other interesting lichenicolous Tremellales and Filobasidiales in the Nordic countries. Mycokeys 8: 31-41. https://doi.org/10.3897/mycokeys.8.8176

Millanes, A.M., Truong, C., Westberg, M., Diederich, P. \& Wedin, M. (2014b) Host switching promotes diversity in host-specialized mycoparasitic fungi: uncoupled evolution in the Biatoropsis-Usnea system. Evolution 68: 1576-1593. https://doi.org/10.1111/evo.12374

Millanes, A.M., Diederich, P., Westberg, M., Pippola, E. \& Wedin, M. (2015) Tremella cetrariellae (Tremellales, Basidiomycota, Fungi), a new lichenicolous fungus on Cetrariella delisei. Lichenologist 47: 359-368. https://doi.org/10.1017/S0024282915000377

Moberg, R. (1977) The lichen genus Physcia and allied genera in Fennoscandia. Symbolae Botanicae Upsalienses 22: 1-108.

Necker, N.M.J. (1771) Methodus Muscorum. XVII + 296 pp.

Okoli, I., Christie, A., Kwon-Chung, K.J., Theelen, B., Robert, V., Groenewald, J.Z., McFadden, D.C., Casadevall, A. \& Boekhout, T. (2007) Cryptotrichosporon anacardii gen. nov., sp. nov., a new trichosporonoid capsulate basidiomycetous yeast from Nigeria that is able to form melanin on niger seed agar. FEMS Yeast Research 7: 339-350. https://doi.org/10.1111/j.1567-1364.2006.00164.x

Olson, D.M., Dinerstein, E., Wikramanayake, E.D., Burgess, N.D., Powell, G.V.N., Underwood, E.C., D’Amico, J.A., Strand, H.E., Morrison, J.C., Loucks, C.J., Allnutt, T.F., Lamoreux, J.F., Ricketts, T.H., Itoua, I., Wettengel, W.W., Kura, Y., Hedao, P. \& Kassem, K. (2001) Terrestrial ecoregions of the world: A new map of life on Earth. BioScience 51: 933-938. https://doi.org/10.1641/0006-3568(2001)051[0933:TEOTWA]2.0.CO;2

Persoon, C.H. (1794) Neuer Versuch einer systematischen Einteilung der Schwämme. Neues Magazin für die Botanik 1: 63-128.

Petkovits, T., Nagy, L.G., Hoffmann, K., Wagner, L., Nyilasi, I., Griebel, T., Schnabelrauch, D., Vogel, H., Voigt, K., Vágvölgyi, C. \& Papp, T. (2011) Data partitions, Bayesian analysis and phylogeny of the zygomycetous fungal family Mortierellaceae, inferred from nuclear ribosomal DNA sequences. PLoS One 6: e27507. https://doi.org/10.1371/journal.pone.0027507

Posada, D. (2008) jModelTest: phylogenetic model averaging. Molecular Biology and Evolution 25: 1253-1256. https://doi.org/10.1093/molbev/msn083

Räsänen, V. (1931) Die Flechten Estlands I. Annales Academiae Scientiarum Fennicae 34: 1-163.

Retzius, A.J. (1769) Anmårkningar vid Skånes Ört-Historie. Kongl. Vetenskaps Academiens Handlingar. Stockholm 30: $243-255$.

Rose, F. (1998) Anaptychia ciliaris ssp. ciliaris. Species account 45/1998 in the third fascicle of the Lichen Atlas of the British Isles. British Lichen Society, London.

Schaeffer, J.C. (1774) Fungorum qui in Bavaria et Palatinatu circa Ratisbonam nascuntur Icones 4.136 pp.

Sérusiaux, E., Diederich, P., Ertz, D. \& van den Boom, P. (2003) New or interesting lichens and lichenicolous fungi from Belgium, Luxembourg and northern France. IX. Lejeunia n. s. 173: 1-48.

Silvestro, D. \& Michalak, I. (2012) RaxmlGUI: a graphical front-end for RAxML. Organisms Diversity and Evolution 12: $335 \mathrm{e} 337$. https://doi.org/10.1007/s13127-011-0056-0

Stamatakis, A. (2006) RAxML-VI-HPC: Maximum Likelihood-based Phylogenetic Analyses with Thousands of Taxa and Mixed Models. Bioinformatics 22: 2688-2690.

https://doi.org/10.1093/bioinformatics/btl446

Vilgalys, R. \& Hester, M. (1990) Rapid genetic identification and mapping of enzymatically amplified ribosomal DNA from several Cryptococcus species. Journal of Bacteriology 172: 4238-4246. https://doi.org/10.1128/jb.172.8.4238-4246.1990

Zamora, J.C., Pérez-Ortega, S. \& Rico, V.J. (2011) Tremella macrobasidiata (Basidiomycota, Tremellales), a new lichenicolous fungus from the Iberian Peninsula. Lichenologist 43: 407-415. https://doi.org/10.1017/S0024282911000405

Zamora, J.C., Millanes, A.M., Wedin, M., Rico, V.J. \& Pérez-Ortega, S. (2016) Understanding lichenicolous heterobasidiomycetes: new taxa and reproductive innovations in Tremella s.l. Mycologia 108: 381-396.

https://doi.org/10.3852/15-090 